\title{
Diversification, Relational Capital and Bank Performance: Evidence from Commercial Banks in China
}

\author{
Shun-Ho Chu ${ }^{1, a}$, Xize Gong ${ }^{2, b}$, Ziyi Fang ${ }^{3, c,}$, , Haoming Lan ${ }^{4, d}$ and Haokai \\ Gou $^{5, e}$ \\ School of Business, Macau University of Science and Technology, Macau, 999078, China \\ ashchu@must.edu.mo, b2037264070@qq.com, cfangziyi399@outlook.com, \\ dIIIIIhm017@gmail.com, ehaokaigou@gmail.com
}

${ }^{*}$ Corresponding author

Keywords: Diversification, relational capital, bank performance

\begin{abstract}
Diversification is a crucial competition strategy for banks. In recent years, some studies posit that relational capital is regarded as an important determinants of bank competitiveness. The study tries to investigate the impact of diversification and relational capital on bank performance by using annual data of 96 Chinese commercial banks over period of 2014-2018. The empirical results of the study show that ratio of non-interest income to operating income (NII) has positive impact on bank performance. Secondly, by adding relational capital (RCI) in the estimation regression model, the interaction of NII and RCI has negative impact on bank performance, whereas the interaction of $\mathrm{NII}$ and $\mathrm{RCI}^{2}$ has U-shape relationship with bank performance.
\end{abstract}

\section{Introduction}

Since joining in WTO in 2000, China government has adopted the opening policy to allow foreign financial institutions enter into domestic financial markets. In recent years, China government has continuously reformed financial policies to improve financial system, such as interest-rate marketization and elimination on ratio of loans to deposits. Facing the changing financial markets, commercial banks should take this opportunity to expand banking business; conversely, banks may earn lubricant profits in traditional banking activities due to high-level market competition.

To further sustainable operation and development, China's commercial banks try to diversify banking activities, especially, by adding wealth management activities in banking portfolios for earning profits. The banking activities added by commercial banks are non-risks or low level-risks activities, which are underwriting of mutual funds and government bonds and marketing of insurance policies.

In practice, enterprises have to create and maintain relationship capital to gain customer and brand loyalty, customer satisfaction, market image, goodwill, bargaining power and strategic alliances. Gogan, Duran and Draghici (2014) considered that relational capital is one of determinants of bank competitiveness [1]. In the context of the knowledge economy, relational capital refers to all intangible assets related to external stakeholders, and is an important source of competitive advantage, which will affect the performance and value of enterprises. Therefore, relational capital of commercial banks has played an important role in the market competitiveness, which is benefit for establishing customer relationship to market financial products.

Previous empirical studies show that diversification has effect on enterprise performance. Using data of 20 Tunisian commercial banks, Hamdi, Hakimi and Zaghdoudi (2017) conclude that ratio of non-interest income to total assets has positive impact on bank performance [2]. The study of Alkhouri and Arouri (2019) also show the positive effect of bank diversification on performance in case of 69 traditional banks and Islamic banks in GCC countries [3]. In addition, some empirical studies conclude that relational capital has effect on enterprise performance. García-Merino, GarcíaZambrano and Rodríguez-Castellanos (2014) find that relational capital affects the company's business value in case of 35 Spanish listed companies [4]. De Clercq and Sapienza (2006) posit that relational capital and commitment affect a venture capital firm's perception of the performance of its 
portfolio companies [5]. Datta and De (2017) find that the relational capital has effect on the performance of bell-metal clustered firms in India [6].

Based on prior empirical studies, the study tries to fulfill the research gap and investigate the impact of diversification and relational capital on bank performance using annual data of Chinese commercial banks from 2014 to 2018. The rest of the study consists of 5 sections. Section 2 discusses literature review and hypotheses. Section 3 provides data and methodology. The empirical results are shown in section 4 . Conclusion is presented in the final section.

\section{Literature Review and Hypotheses}

Diversification is one of important business strategies for commercial banks to earn more profits and undertake lower risks. Non-interest income activities are the diversified banking services, including no-risk or low-risk financial services of foreign exchange trading and remittance transactions and risky financial services of letter of credit, letter of guarantee, guarantee for commercial paper, banker's acceptance, foreign exchange forward transactions. In addition, the commercial banks also as agents to sell insurance products for the insurance industry and mutual fund products for the securities investment industry to obtain brokerage fees and commissions.

Prior studies have evidence that bank non-interest income or income diversification have a positive impact on performance. Lee, Yang and Chang (2014) examine the impact of non-interest income on bank profitability with data from 967 banks in 22 Asian countries from 1995 to 2009. The results of the study show that non-interest income has no impact on bank profitability. Secondly, the study divides the sample banks into five banking groups of bank-holding companies, commercial banks, cooperative banks, investment banks and savings banks. Among them, the non-interest income of the cooperative bank has a positive impact on the bank's profitability (ROA), and the non-interest income of the savings bank has a negative impact on the bank's profitability (ROA). Furthermore, the noninterest income of investment banks has a positive impact on bank profitability (ROA) [7]. Ferreira, Zanini and Alves (2019) employ 1,019 data from Brazilian commercial banks, investment banks, development banks and other banks from 2003 to 2014 by using panel data methods to analyze the impact of bank income diversification on risk and return. The empirical results show that bank noninterest income (NII) and income concentration (HHI) have a positive impact on business performance (ROA) [8].

Then, the study presents the following hypotheses.

Hypotheses 1: Diversification has positive effect on bank performance.

Kale et al. (2000) think that relational capital involves the level of mutual trust, respect and friendship that arises out of close interactions between internal and external partners is the main theme of relational capital [9]. Chen et al. (2004) define relational capital as an intangible asset that is based on the developing, maintaining and nurturing high quality relationship with any organization, individual or group that influences or impacts the business including customers, suppliers, employees, government, partners, competitors and any other stakeholders [10]. De Clercqa \& Sapienzab (2006) define relational capital as the extent to which exchange involves trust, social interaction and shared norms or goals. In other words, the key issue in gaining competitiveness is the ability to convert those intangible assets into value and to leverage that value in its market place [5].

Chen et al. (2004) recognize that relational capital as a bridge and a catalyst that acts in the operations of the intangible assets. It is the main requirement and determines the conversion of intangible resources in market value and also in organizational competitiveness [10]. And companies with political connections are more likely to enter the financial industry than those without political connections, and can also obtain more bank loans and longer-term loans.

Sulait (2010) and Raza (2013) think that market value or organizational competitiveness cannot be achieved without relational capital, so relational capital is directly linked to business performance. Therefore, relational capital has a key role in the financial markets. It is shown in some study that relational capital explains 3.28 percent of the variance in company performance $[11,12]$. Sydler et al. (2014) provide a method for measuring the intellectual capital and its impact on company performance via quantitative evaluations and show that relational capital explains long-term 
differences in the profitability of organizations [13].

Then, the study would present the following hypotheses.

Hypotheses 2-1: Relational capital having an interaction with diversification has positive effect on bank performance.

Hypotheses 2-2: Relational capital having an interaction with diversification has U-shape relationship with bank performance.

\section{Data and Methodology}

Annual data over the period from 2014 to 2018 are collected from CSMAR. The samples of the study are 96 Chinese commercial banks including 6 state-owned banks, 67 joint-stock banks and 23 city commercial banks.

Referring to the studies of Esho, Kaufman and Sharpe (2005) and Williams and Prather (2010), this study employs return on asset (ROA) to measure bank performance as dependent variable [14, 15]. Following to the study of Kohler (2014), the study uses ratio of non-interest income to total operating income (NII) and HHI to measure bank diversification as independent variables [16]. In addition, the study adds asset size, growth rate of real GDP and ratio of loans to deposits in the estimation regression.

Furthermore, the study constructs relational capital index (RCI) by five factors including government relationship, shareholder relationship, employee relationship, depositor relationship and lender relationship by applying entropy model.

For the research purpose, the study constructs the following research models.

$$
\begin{array}{r}
\mathrm{ROA}_{\mathrm{it}}=\alpha_{0}+\gamma_{1} \mathrm{NII}_{\mathrm{it}}+\gamma_{2} \mathrm{HHII}_{\mathrm{it}}+\gamma_{3} \mathrm{SIZE}_{\mathrm{it}}+\gamma_{4} \mathrm{LDR}_{\mathrm{it} .}+\gamma_{5} \mathrm{RGDP}_{\mathrm{t}}+\varepsilon_{\mathrm{it}} \\
\mathrm{ROA}_{\mathrm{it}}=\alpha_{0}+\gamma_{1} \mathrm{NII}_{\mathrm{it}}+\gamma_{2} \mathrm{HHI}_{\mathrm{it}}+\gamma_{3} \mathrm{RCI}_{\mathrm{it}}+\gamma_{4} \mathrm{RCI}^{2}+\gamma_{5} \mathrm{NII}_{\mathrm{it}} * \mathrm{RCI}_{\mathrm{it}}+\gamma_{6} \mathrm{HHI}_{\mathrm{it}} * \mathrm{RCI}_{\mathrm{it}}+\gamma_{7} \mathrm{NII}_{\mathrm{it}} * \mathrm{RCI}^{2}{ }_{\mathrm{it}}+ \\
\gamma_{8} \mathrm{HHI}_{\mathrm{it}} * \mathrm{RCI}^{2}{ }_{\mathrm{it}}+\gamma_{9} \mathrm{SIZE}_{\mathrm{it}}+\gamma_{10} \mathrm{LDR}_{\mathrm{it}}+\gamma_{11} \mathrm{RGDP}_{\mathrm{t}}+\varepsilon_{\mathrm{it}}
\end{array}
$$

Where,

$\mathrm{ROA}_{\mathrm{it}}$ : return on assets in the $\mathrm{i}$ bank at the $\mathrm{t}$ year.

$\mathrm{NII}_{\mathrm{it}}$ : ratio of non-interest income to operating income in the $\mathrm{i}$ bank at the t-year.

$\mathrm{HHI}_{\mathrm{it}}$ : income diversification index in the $\mathrm{i}$ bank at the $\mathrm{t}$ year.

$\mathrm{RCI}_{\mathrm{it}}$ : relational capital index in the $\mathrm{i}$ bank at the $\mathrm{t}$ year.

SIZE $\mathrm{it}_{\mathrm{i}}$ : natural logarithm of total assets in the $\mathrm{i}$ bank at the $t$ year.

$L_{D R}$ it: ratio of loans to deposits in the $i$ bank at the $t$ year.

$\mathrm{RGDP}_{\mathrm{t}}$ : growth rate of real GDP at the $\mathrm{t}$ year.

$\alpha_{0}$ : constant item.

$\gamma$ : coefficient.

$\varepsilon:$ an error item.

\section{Empirical Results}

\subsection{Correlation analysis}

Based on correlation analysis shown in Table 1, correlation coefficients between any two variables among independent variable and control variable are less than 0.700 , indicating that there is no collinearity between the variables which can independently explain dependent variable.

Table 1. Correlation Analysis

\begin{tabular}{lcccccc}
\hline Variables & NII & HHI & RCI & SIZE & LDR & RGDP \\
\hline NII & 1.000 & & & & & \\
HHI & -0.144 & 1.000 & & & & \\
RCI & -0.263 & 0.037 & 1.000 & & & \\
SIZE & -0.024 & -0.114 & -0.038 & 1.000 & & \\
LDR & 0.324 & 0.132 & -0.088 & 0.238 & 1.000 & \\
RGDP & -0.035 & -0.114 & -0.299 & -0.033 & 0.002 & 1.000 \\
\hline
\end{tabular}




\subsection{Hausman test}

According to the results of Hausman tests shown in Table 2, both of model 1 and model 2 should select random effect model in regression model.

Table 2. Hausman Test

\begin{tabular}{lccl}
\hline Model & Chi-Sq. Stat & Chi-Sq. d.f. & Prob. \\
\hline Model 1 & 0.002 & 5 & 1.000 \\
Model 2 & 0.000 & 10 & 1.000 \\
\hline
\end{tabular}

\subsection{Regression analysis}

Empirical results of model 1 and model 2 are shown in Table 3. Referring to model 1, NII has positive impact on bank performance, which supports hypotheses 1, whereas HHI has no impact on bank performance, which does not support hypotheses 1 . As for model 2 by adding the variable of relational capital (RCI), the interaction of NII and RCI has negative impact on bank performance, which does not support hypotheses 2-1, whereas the interaction of NII and $\mathrm{RCI}^{2}$ has U-shape relationship with bank performance, which support hypotheses 2-2. In addition, the interaction of HHI and RCI as well as the interaction of $\mathrm{HHI}$ and $\mathrm{RCI}^{2}$ have no impact on bank performance, which do not support hypotheses 2-1 and 2-2.

Table 3 Empirical results of the OSL regression

\begin{tabular}{|c|c|c|}
\hline Variables & $\begin{array}{c}\text { Model } 1 \\
\text { ROA }\end{array}$ & $\begin{array}{c}\text { Model } 2 \\
\text { ROA }\end{array}$ \\
\hline $\mathrm{C}$ & $\begin{array}{c}-0.022 * * * \\
(0.005)\end{array}$ & $\begin{array}{r}-0.212 * * * \\
(0.005)\end{array}$ \\
\hline NII & $\begin{array}{c}0.000 * * * \\
(0.000)\end{array}$ & $\begin{array}{c}0.000 * * * \\
(0.000)\end{array}$ \\
\hline HHI & $\begin{array}{c}-0.001 \\
(0.001)\end{array}$ & $\begin{array}{l}-0.005 \\
(0.003)\end{array}$ \\
\hline $\mathrm{RCI}$ & & $\begin{array}{c}0.000 \\
(0.005)\end{array}$ \\
\hline $\mathrm{RCI}^{\wedge} 2$ & & $\begin{array}{l}-0.000 \\
(0.002)\end{array}$ \\
\hline NII*RCI & & $\begin{array}{c}-0.000 * * * \\
(0.000)\end{array}$ \\
\hline HHI*RCI & & $\begin{array}{c}0.000 \\
(0.006)\end{array}$ \\
\hline $\mathrm{NII} * \mathrm{RCI}^{2}$ & & $\begin{array}{c}0.000 * * * \\
(0.000)\end{array}$ \\
\hline $\mathrm{HHI}^{*} \mathrm{RCI}^{2}$ & & $\begin{array}{c}0.000 \\
(0.002)\end{array}$ \\
\hline SIZE & $\begin{array}{l}-0.000 \\
(0.000)\end{array}$ & $\begin{array}{c}-0.000 * * * \\
(0.000)\end{array}$ \\
\hline LDR & $\begin{array}{c}0.003 * * * \\
(0.0009)\end{array}$ & $\begin{array}{c}0.003 * * * \\
(0.001)\end{array}$ \\
\hline RGDP & $\begin{array}{c}0.439 * * * \\
(0.063)\end{array}$ & $\begin{array}{c}0.417 * * * \\
(0.063)\end{array}$ \\
\hline $\mathrm{R}$-squared & 0.692 & 0.221 \\
\hline
\end{tabular}

Note: * denotes significance at level of $10 \% ; * *$ denotes significance at level of $5 \%$; *** denotes significance at level of $1 \%$. Values in the parenthesis are standard errors.

\section{Conclusion}

The purpose of this study is to investigate the effect of diversification and relational capital on bank performance by using samples of 96 commercial banks in China spanning the period from 2014 to 2018. According to the empirical analysis, the conclusions of the study show that ratio of non-interest income to operating income (NII) has positive impact on bank performance. Secondly, the interaction of NII and RCI has negative impact on bank performance, whereas the interaction of NII and $\mathrm{RCI}^{2}$ 
has U-shape relationship with bank performance.

According to empirical results, this study presents the following suggestions.

Firstly, commercial banks should enhance non-interest income banking activities complied with the study conclusion of Lee, Yang and Chang (2014) [7]. By providing full-range financial services with no-risk or low-risk level, commercial banks can earn profits and undertake low risks, and bank customers can get satisfactory financial service for their transactions.

Secondly, even though relational capital interacted with non-interest income has negative impact on bank performance, relational capital interacted with non-interest income has U-shape relationship with bank performance. As commercial banks provide interest income and non-interest income financial services, they should establish long-term relationships with customers to reduce information asymmetry, lower transaction costs and increase revenues. Therefore, in addition to paying attention to the benefits of financial products, banks should establish information data on transactions between customers and banks to increase operating income and reduce bank risks.

\section{Reference}

[1] Gogan, M. L., Duran, D. C., \& Graghici, A. (2014). The impact of relational capital on competitiveness of organizations. Network Intelligence Studies, 2(2), 233-240.

[2] Hamdi, H., Hakimi, A., \& Zaghdoudi, K. (2017). Diversification, bank performance and risk: Have Tunisian banks adopted the new business model? Financial Innovation, 3, 22-46.

[3] Alkhouri, R., \& Arouri, H. (2019). The effect of diversification on risk and return in banking sector Evidence from the Gulf Cooperation Council countries. International Journal of Managerial Finance, 15(1), 100-128.

[4] García-Merino, J. D., García-Zambrano, L., \& Rodríguez-Castellanos, A. (2014). Impact of relational capital on business value. Journal of Information and Knowledge Management, 13(1), 735-741.

[5] De Clercq, D., \& Sapienza, H. J. (2006). Effects of relational capital and commitment on venture capitalists' perception of portfolio company performance. Journal of Business Venturing, 21, 326 -347 .

[6] Datta, S. K., \& De, T. (2017). Role of relational capital and firm performance: analysis of a cluster of bell-metal enterprises in a rural region in west Bengal, India. Journal of Entrepreneurship \& Organization Management, 6(1), 1-6.

[7] Lee, C.C, Yang, S. J, and Chang, C.H. (2014). Non-interest income, profitability, risk in banking industry: A cross-country analysis. North American Journal of Economic and finance, 17, 48 -67.

[8] Ferreira, J.H.L, Zanini, F.A.M. and Alves, T.W., Bamnk. (2019). revenue diversification: Its impact on its risk and return in Brazilian banks. Accounting and Finance Review, 30(79), 91-106.

[9] Kale, p, Singh, H. (2000). Learning and protection of proprietary assets in strategical alliances: Building relational capital. Strategic Management Journal,21, 217-317.

[10] Chen, J., Zhue, Z. and Zie, H.Y. (2004). Measuring intellectual capital: a new model and empirical study. Journal of Intellectual Capital, 5(1), 195-212.

[11] Sulait, T. (2010). Relational capital and firm performance: a case of manufacturing tea firms in Uganda. doctoral dissertation, Makerere University, Kampala.

[12] Raza, A. (2013). Impact of relational capital management on firm performance. Abasyn University Journal of Social Sciences,6(1), 65-78.

[13] Sydler, R., Haefliger, S. and Pruksa, R. (2014). Measuring intellectual capital with financial figures: can we predict firm performance. European Management Journal,32(2), 244-259. 
[14] Esho, N, Kaufman, P. and Sharpe, I. (2005). Diversification, fee income and credit union bank risk. Journal of Financial Services Research, 27: 259-281.

[15] Williams, B. and Prather, L. (2010). Bank risk and return: The impact of bank non-interest income. International Journal of Managerial Finance, 6(3), 220-244.

[16] Kohler, M. (2014). Does non-interest income make banks riskier? Retail-versus investmentoriented banks. Review of Financial Economics, 23, 182-193. 